\title{
GAMBARAN TINGKAT PENGETAHUAN \\ DAN KEBERSIHAN MULUT PADA MASYARAKAT LANJUT USIA DI KELURAHAN RURUKAN KECAMATAN TOMOHON TIMUR
}

\author{
${ }^{1}$ Niyan Nidyawati \\ ${ }^{2}$ Dinar A. Wicaksono \\ ${ }^{2}$ Joenda S. Soewantoro \\ ${ }^{1}$ Kandidat Skripsi Fakultas Kedokteran Universitas Sam Ratulangi Manado \\ ${ }^{2}$ Program Studi Kedokteran Gigi Fakutas Kedokteran Universitas Sam Ratulangi Manado \\ Email: nanbum91mir@gmail.com
}

\begin{abstract}
Knowledge has an important role in improving people's behavior. Awareness of oral hygiene is essential for its good maintainance; therefore, prevention of oral diseases, improvement of immunity, reparation of oral functions and appetite can be achieved. In general, the elderly have a decline in their immune system, which makes them more susceptible to diseases, including oral diseases; thus, maintaining an oral hygiene status is very valuable. This study aimed to reveal the level of knowledge about oral hygiene, and the oral hygiene status among the elderly in Rurukan, East Tomohon. This was a descriptive study with a cross sectional design. Samples were obtained by using a total sampling method. Total samples were 71 elderly, but only 50 met the inclusion criteria. The results showed that 27 elderly had low levels of oral hygiene knowledge, while 23 elderly had good levels of knowledge. The status of oral hygiene was poor in 34 elderly, moderate in 13, and good in 3. Conclusion: Most of the elderly in Rurukan, East Tomohon, had low levels of oral hygiene knowledge and poor status of oral hygiene.
\end{abstract}

Keywords: knowledge, oral hygiene, elderly.

\begin{abstract}
Abstrak: Pengetahuan berperan penting dalam perkembangan perilaku seseorang. Pengetahuan yang baik mengenai kebersihan mulut sangat penting untuk mencegah penyakit gigi dan mulut, meningkatkan daya tahan tubuh, dan memperbaiki fungsi mulut untuk memperbaiki nafsu makan. Pada lanjut usia (lansia) terjadi penurunan daya tahan tubuh yang menyebabkannya rentan terhadap penyakit. Menjaga kebersihan mulut merupakan salah satu cara menjaga kondisi tubuh lansia. Penelitian ini bertujuan untuk mendapatkan gambaran tingkat pengetahuan dan kebersihan mulut pada masyarakat lansia di Kelurahan Rurukan Kecamatan Tomohon Timur. Penelitian ini bersifat deskriptif dengan cross sectional design. Dengan metode total sampling diperoleh 71 sampel penelitian tetapi hanya 50 yang memenuhi kriteria. Hasil penelitian menunjukkan bahwa tingkat pengetahuan dan kebersihan mulut masyarakat lansia masih sangat minim. Untuk tingkat pengetahuan mengenai kebersihan mulut diperoleh 27 orang lansia dengan tingkat pengetahuan kurang, sedangkan 23 lainnya dengan tingkat pengetahuan baik. Untuk status kebersihan mulut diperoleh 34 orang lansia dengan hasil buruk, 13 dengan hasil sedang, dan 3 dengan hasil baik. Simpulan: Sebagian besar masyarakat lansia di Kelurahan Rurukan Kecamatan Tomohon Timur memiliki tingkat pengetahuan kurang dan status kebersihan mulut buruk.
\end{abstract}

Kata kunci: pengetahuan, kebersihan mulut, lansia. 
Lanjut usia (lansia) merupakan suatu proses alami dimana terjadi perubahan fungsi jaringan tubuh dan organ yang sangat kompleks, termasuk perubahan jaringan mulut. Lansia ditandai dengan penurunan kemampuan berbagai jaringan tubuh secara perlahan-lahan untuk memperbaiki diri atau mengganti dan mempertahankan fungsi normal. ${ }^{1}$ Selain kondisi fisik, kondisi psikis juga mengalami penurunan. ${ }^{2}$ Penurunan kondisi ini terjadi pada berbagai organ tubuh, antara lain melemahnya daya ingat, perubahan sensorik fisik yang melibatkan berbagai indera (penglihatan, pendengaran, perasa, penciuman, peraba), serta gangguan pada gigi. ${ }^{3}$

Kebersihan mulut pada lansia harus dijaga mengingat berbagai perubahan yang terjadi yaitu penipisan mukosa mulut, penurunan produksi saliva, dan tanggalnya gigi. ${ }^{4}$ Banyaknya gigi pada lansia juga dipengaruhi oleh kebersihan gigi dan mulut. Kebersihan mulut yang buruk dapat mengakibatkan iritasi dan gangguan kesehatan gusi serta permukaan gigi. ${ }^{5}$

Gangguan pada gigi berakibat lanjut penurunan nafsu makan dan penurunan berat badan, serta gigi tersebut menjadi fokus infeksi. Selain itu, penurunan kesehatan dan daya tahan tubuh lansia akan mempermudah terjadinya infeksi mukosa pada rongga mulut dan jaringan periodontal. ${ }^{5}$

Tingkat pengetahuan lansia mengenai kesehatan mulut merupakan salah satu faktor penting yang memengaruhi kebersihan mulut. Pengetahuan dapat berupa domain kognitif yang sangat penting untuk terbentuknya tindakan. Perilaku yang dilandasi pengetahuan akan lebih langgeng dibandingkan yang tanpa dilandasi pengetahuan. Tingkat pengetahuan tersebut dapat dipengaruhi oleh status pendidikan, status sosial ekonomi, maupun peran serta keluarga. ${ }^{6}$

Kebersihan mulut (oral hygiene) merupakan tindakan membersihkan dan menyegarkan mulut, gigi, dan gingiva. Tindakan ini dilakukan untuk mencegah penyakit gigi dan mulut, mencegah penyakit yang penularannya melalui mulut, meningkatkan daya tahan tubuh, dan memperbaiki fungsi mulut untuk meningkatkan nafsu makan. ${ }^{7}$ Kondisi mulut yang tidak sehat, khususnya pada lansia, dapat memengaruhi kesehatan tubuh secara umum, bahkan dapat menyebabkan rasa sakit, kehilangan gigi, serta kesulitan dalam berbicara, mengunyah, dan menelan. ${ }^{8}$

Masyarakat di Kelurahan Rurukan, Kecamatan Tomohon Timur sebagian besar berprofesi sebagai petani. Hasil survei awal memperlihatkan bahwa masyarakat di kelurahan tersebut sebagian besar memiliki status ekonomi rendah, yang mungkin memengaruhi tingkat pengetahuan dan kesehatan, khususnya kesehatan gigi dan mulut.

\section{METODE PENELITIAN}

Penelitian ini merupakan penelitian deskriptif dengan cross-sectional design. Sampel ialah masyarakat lansia berusia 5559 tahun di Kelurahan Rurukan Kecamatan Tomohon Timur yang berjumlah 71 orang. Sampel diperoleh dengan menggunakan metode total sampling. Variabel bebas ialah pengetahuan lansia terhadap kebersihan mulut, sedangkan variabel terikat ialah oral hygiene index simplified (OHI-S).

Pengumpulan data dilakukan dengan wawancara mengenai tingkat pengetahuan tentang kebersihan mulut dan pemeriksaan OHI-S pada setiap responden. Untuk tingkat pengetahuan dilakukan wawancara menggunakan panduan wawancara yang mengandung 9 pertanyaan. Setiap pertanyaan diberi skor yaitu untuk jawaban benar diberi skor 1, dan jawaban salah diberi skor 0. Skor dijumlahkan dan hasilnya dikelompokkan berdasarkan kategori: baik bila nilai yang diperoleh $>50 \%$ dari nilai tertinggi, dengan kisaran nilai 5-9; dan kurang bila nilai yang diperoleh $<50 \%$, dengan kisaran nilai $0-4$.

Pemeriksaan OHI-S dilakukan dengan pengukuran indeks debris dan kalkulus. Bagian gigi yang diperiksa ialah permukaan fasial/bukal dan permukaan lingual. Setiap permukaan gigi dibagi secara horisontal menjadi tiga bagian, yaitu: 1/3 
gingival, $2 / 3$ gingival, dan $1 / 3$ insisal atau lebih dari $2 / 3$ gingival. ${ }^{9}$

Pengukuran dilakukan dengan penjumlahan indeks debris dan indeks kalkulus yang sebelumnya telah disesuaikan dengan tabel kriteria (Tabel 1,2) dan dijumlahkan secara terpisah.

Tabel 1. Kriteria penilaian indeks debris ${ }^{10}$

\begin{tabular}{cc}
\hline Kriteria & Nilai \\
\hline Pada permukaan gigi yang terlihat, & 0 \\
tidak terdapat debris atau stain & \\
Pada permukaan gigi terdapat debris & \\
lunak yang menutupi $<1 / 3$ atau $>1 / 3$ & 1 \\
permukaan gigi & \\
Pada permukaan gigi terdapat debris & \\
lunak yang menutupi $>1 / 3$ atau $<2 / 3$ & 2 \\
permukaan gigi & \\
Pada permukaan gigi yang terlihat, & \\
terdapat debris lunak yang & 3 \\
menutupi $>2 / 3$ permukaan gigi atau & \\
seluruh permukaan gigi & \\
\hline
\end{tabular}

Tabel 2. Kriteria penilaian indeks kalkulus ${ }^{10}$

\begin{tabular}{cc}
\hline Kriteria & Nilai \\
\hline Pada permukaan gigi yang terlihat, & 0 \\
tidak terdapat indeks kalkulus & \\
Pada permukaan gigi terdapat indeks & \\
kalkulus lunak yang menutupi $<1 / 3$ & 1 \\
atau $>1 / 3$ permukaan gigi & \\
Pada permukaan gigi terdapat indeks & \\
kalkulus lunak yang menutupi $>1 / 3$ & 2 \\
atau $<2 / 3$ permukaan gigi & \\
Pada permukaan gigi yang terlihat, \\
terdapat indeks kalkulus lunak \\
yang menutupi $>2 / 3$ permukaan gigi \\
atau seluruh permukaan gigi
\end{tabular}

Skor yang diperoleh dari tabel kriteria tersebut dijumlahkan secara terpisah sesuai rumus indeks debris dan indeks kalkulus. Rumus indeks debris ialah: ${ }^{7}$

Indeks debris $(\mathrm{DI})=\frac{\text { jumlah penilaian indeks }}{\text { jumlah gigi } \mathrm{y} \text { ang diperiksa }}$

Rumus indeks kalkulus ialah: ${ }^{7}$

Indeks kalkulus $(\mathrm{CI})=\frac{\text { jumlah penilaian indeks }}{\text { jumlah gigi } \mathrm{y} \text { ang diperiksa }}$
Hasil akhir OHI-S diperoleh dengan menjumlahkan hasil indeks debris dan indeks kalkulus sesuai dengan rumus OHI$\mathrm{S}$, yaitu OHI-S = DI + CI. ${ }^{9}$ Hasil tersebut disesuaikan dengan penilaian skor OHI-S sebagai berikut: 1) Baik (good), bila nilai 01,$2 ; 2$ ) Sedang (fair), bila nilai 1,3-3,0; dan 3) Buruk (poor), bila nilai 3,1-6,0. ${ }^{10}$

\section{HASIL PENELITIAN}

Penelitian ini dilakukan di Kelurahan Rurukan Kecamatan Tomohon Timur pada tanggal 24 September-7 Oktober 2012 dengan 50 orang responden yang memenuhi kriteria inklusi.

Karakteristik subjek penelitian berdasarkan jenis kelamin menunjukkan jumlah dan persentase yang berbeda-beda. Usia 59 tahun sebagai jumlah sampel terbanyak (14 orang, 28\%) dengan jenis kelamin laki-laki 9 orang dan perempuan 5 orang. Usia 57 tahun dan 58 tahun merupakan sampel dengan jumlah terkecil, dengan sampel total masing-masing 8 orang (16\%) (Gambar 1).

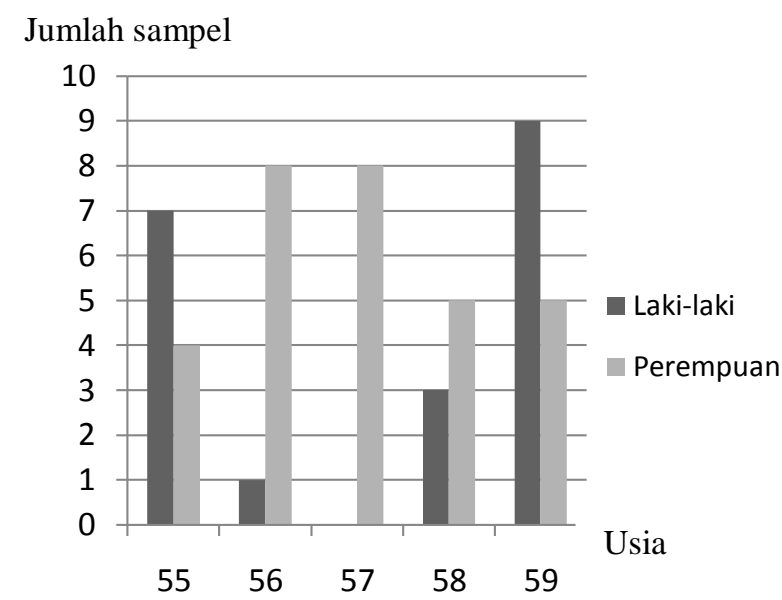

Gambar 1. Distribusi subjek penelitian berdasarkan jenis kelamin dan usia.

Karakteristik subjek mengenai jumlah dan persentase sampel berdasarkan tingkat pengetahuan tentang kebersihan mulut menunjukkan bahwa masyarakat lansia yang berpengetahuan baik berjumlah 23 orang $(46 \%)$ dan berpengetahuan kurang 
berjumlah 27 orang (54\%). Usia 55 tahun, 56 tahun, dan 59 tahun merupakan sampel terbanyak yang memiliki pengetahuan yang baik mengenai kebersihan mulut dengan jumlah sampel yang sama yaitu berjumlah 6 orang (12\%), diikuti usia 58 tahun dengan jumlah sampel 3 orang $(6 \%)$ dan usia 57 tahun dengan jumlah sampel 2 orang $(4 \%)$. Lansia yang memiliki tingkat pengetahuan kurang mengenai kebersihan mulut terbanyak pada usia 59 tahun dengan jumlah sampel 8 orang (16\%) (Gambar 2).

\section{Jumlah sampel}

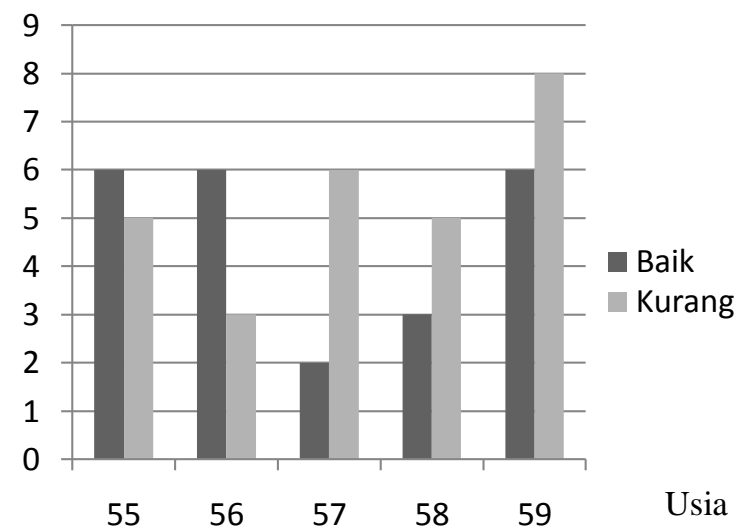

Gambar 2. Distribusi subjek penelitian berdasarkan tingkat pengetahuan.

Karakteristik subjek penelitian yang menunjukan jumlah dan persentase sampel berdasarkan status kebersihan mulut didapatkan masyarakat lansia dengan status kebersihan mulut baik berjumlah 3 orang (8\%), status kebersihan mulut sedang berjumlah 13 orang (26\%), dan status kebersihan mulut buruk berjumlah 34 orang (66\%). Usia 55 tahun, 57 tahun, dan 59 tahun dengan status kebersihan mulut baik memiliki jumlah sampel yang sama yaitu masing-masing berjumlah 1 orang (2\%), sedangkan usia 56 tahun dan 58 tahun tidak didapati sampel dengan status kebersihan mulut yang baik. Untuk status kebersihan mulut sedang, sampel terbanyak pada usia 59 tahun dengan jumlah 5 orang (10\%), sedangkan yang paling sedikit yaitu pada usia 57 tahun dimana tidak ada sampel yang memiliki status kebersihan mulut sedang. Untuk status kebersihan mulut buruk, sampel terbanyak juga pada usia 59 tahun dengan jumlah sampel 8 orang (16\%), sedangkan yang paling sedikit pada usia 58 tahun dengan jumlah 5 orang (10\%) (Gambar 3).

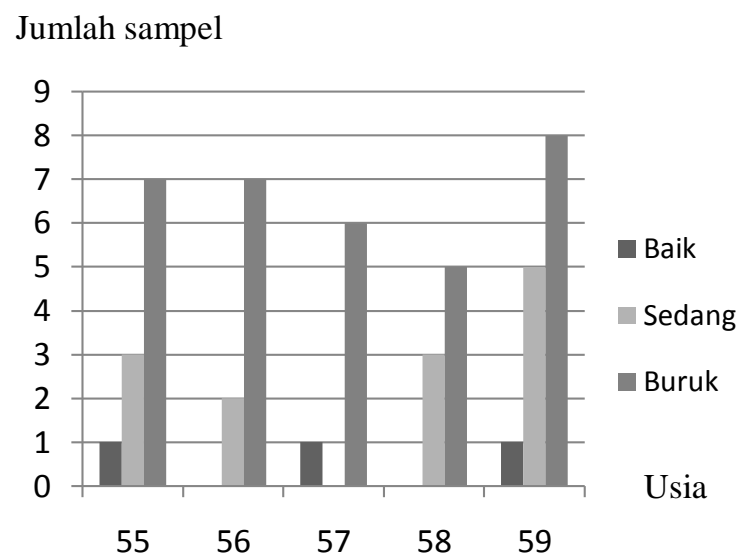

Gambar 3. Distribusi subjek penelitian berdasarkan status kebersihan mulut.

\section{BAHASAN}

Pada penelitian ini jumlah masyarakat lansia perempuan lebih banyak dari lakilaki yaitu jumlah perempuan 30 orang (60\%) dan laki-laki 20 orang (40\%). Sampel terbanyak pada usia 59 tahun sedangkan sampel yang paling sedikit pada usia 57 tahun dan 58 tahun (Gambar 1). Tidak terdapat sampel dengan jenis kelamin laki-laki diusia 57 tahun. Hal ini dikarenakan lansia laki-laki diusia 57 tahun di Kelurahan Rurukan Kecamatan Tomohon Timur kurang kooperatif dan tidak bersedia untuk menjadi sampel selama pengambilan data.

Untuk tingkat pengetahuan mengenai kebersihan mulut didapatkan lansia yang berpengetahuan kurang (54\%) lebih banyak dari pada yang berpengetahuan baik (46\%) (Gambar 2). Pengetahuan merupakan hasil dari 'tahu' dan terjadi setelah seseorang melakukan penginderaan terhadap objek tertentu melalui pancaindra manusia, yakni penglihatan, pendengaran, penghidu, perasa, dan peraba. Sebagian besar pengetahuan manusia diperoleh melalui mata dan 
telinga. Pengetahuan sangat penting dalam membentuk tindakan seseorang. ${ }^{11}$

Banyaknya lansia yang memiliki pengetahuan buruk mengenai kebersihan mulut dapat disebabkan karena tingkat pendidikan yang rendah; sebagian besar hanya lulusan sekolah dasar. Faktor pendidikan merupakan faktor kedua terbesar dari faktor sosial ekonomi yang berpengaruh terhadap pengetahuan sehingga seseorang yang memiliki tingkat pendidikan yang tinggi akan memiliki pengetahuan dan sikap yang baik tentang kesehatan diri dan mulutnya dan akan memengaruhi perilakunya untuk hidup sehat. ${ }^{12}$

Masyarakat lansia di Kelurahan Rurukan sebagian besar memiliki status sosial ekonomi yang rendah yang memengaruhi rendahnya pengetahuan mengenai pentingnya kebersihan mulut. Kurangnya informasi mengenai kebersihan mulut juga merupakan salah satu faktor yang memengaruhi banyaknya masyarakat lansia dengan pengetahuan buruk mengenai kebersihan mulut. Masyarakat lansia di Kelurahan Rurukan sebagian besar hanya memperoleh informasi dari media masa dan keluarga maupun teman yang bukan merupakan tenaga kesehatan. Hasil penelitian ini serupa dengan penelitian Yulaikha ${ }^{13}$ yang melaporkan bahwa lansia dengan pengetahuan kurang baik lebih banyak daripada yang memiliki pengetahuan baik. Dalam penelitian tersebut juga dijelaskan bahwa pengetahuan yang kurang baik memengaruhi sikap dan perilaku lansia di lokasi penelitian.

Pada penelitian ini didapatkan bahwa status kebersihan mulut yang buruk pada masyarakat lansia (66\%) yang paling banyak ditemukan. Berdasarkan usia, yang terbanyak memiliki status kebersihan mulut yang baik yaitu usia 55 tahun, 57 tahun, dan 59 tahun dengan jumlah sampel yang sama yaitu masing-masing berjumlah 1 orang $(2 \%)$, kemudian untuk status kebersihan mulut sedang terbanyak yaitu usia 59 tahun dengan jumlah sampel 5 orang (10\%), dan untuk status kebersihan mulut buruk terbanyak yaitu usia 59 tahun dengan jumlah sampel 8 orang (16\%) (Gambar 3).
Hal yang serupa juga dilaporkan oleh Cahyati $^{14}$ bahwa status kebersihan mulut pada lansia di Panti Werda di Semarang sebagian besar memiliki status kebersihan mulut yang buruk. Pada penelitian tersebut $100 \%$ lansia yang dijadikan sampel memiliki status kebersihan mulut buruk.

Status kebersihan mulut yang buruk dapat dipengaruhi oleh pengetahuan tentang kebersihan mulut individu itu sendiri. Bila cara hidup sehat dalam memelihara kesehatan mulut terbentuk dari pengetahuan yang baik maka status kebersihan mulut juga akan menjadi baik. Sebaliknya, bila pengetahuan memelihara kebersihan mulut kurang baik maka status kebersihan mulut juga akan menjadi buruk sehingga cenderung berisiko mudah terserang karies dan penyakit mulut. Penelitian Ratnasari ${ }^{15}$ menyatakan bahwa terdapat pengaruh positif pada lansia sesudah mendapat pendidikan kesehatan; lansia menjadi lebih memperhatikan kebersihan dan kesehatannya dibandingkan sebelumnya.

Sikap dan tindakan menjaga kebersihan mulut juga dapat memengaruhi perilaku seseorang terhadap kebersihan mulutnya. Terdapat beberapa lansia dengan pengetahuan baik tentang pentingnya kebersihan mulut tetapi memiliki status kebersihan mulut yang buruk. Hal ini mungkin disebabkan sikap negatif seseorang dalam menyerap pengetahuan yang diperoleh tetapi tidak menerapkannya dalam tindakan dan perilaku sehari-hari.

\section{SIMPULAN}

Dari hasil penelitian dapat disimpulkan bahwa sebagian besar masyarakat lansia di Kelurahan Rurukan Kecamatan Tomohon Timur memiliki tingkat pengetahuan kurang dan status kebersihan mulut buruk.

\section{SARAN}

Perlu dilakukan penelitian lanjutan dengan sampel yang lebih banyak dan usia yang lebih bervariasi agar dapat diperoleh gambaran populasi yang lebih rinci. 
Perlu dilakukan penyuluhan mengenai kesehatan gigi dan mulut pada masyarakat di Kelurahan Rurukan Kecamatan Tomohon Timur, khususnya masyarakat lansia.

\section{DAFTAR PUSTAKA}

1. Suparyanto. Konsep lanjut usia (lansia). [online] 2010 [cited 2010 Jul 10]. Available from: URL: http://drsuparyanto.blogspot.com/2010/07/kons ep-lanjut-usia-lansia.html.

2. Wijayanti. Hubungan kondisi fisik RTT lansia terhadap kondisi sosial lansia di RW 03 RT 05 Kelurahan Tegalsari Kecamatan Candisari. Jurnal Ilmiah Perancangan Kota dan Pemukiman ENCLOSURE. 2008;7(1):38-49.

3. Adawiyah AN. Perkembangan fisik dan kognitif dewasa akhir [homepage on the Internet]. 2011 [cited 2011 Feb 1]. Available from: URL: http://blog.uinmalang.ac.id/azzqie/2011/02/01/perkem bangan-fisik-dan-kognitif-dewasaakhir/

4. Putro BC. Perilaku (pengetahuan, sikap, dan tindakan) lansia dalam merawat kebersihan gigi dan mulut di Dusun Krajan Desa Jambon Kecamatan Gemawang Kabupaten Temanggung [Skripsi]. Medan: Fakultas Kedokteran Gigi Universitas Sumatera Utara; 2011.

5. Asni AM. Pengaruh karang gigi terhadap kesehatan gusi pada anak kelas IV dan V SD Negeri Limbung Putri Kecamatan Bajeng Kabupaten Gowa Tahun 2008. Jurnal Media Kesehatan Gigi. 2010;1:24.

6. Parmelia SM. Gambaran perilaku lanjut usia (lansia) tentang kebersihan perorangan di Kelurahan Pasar Merah Barat Kecamatan Medan Kota [Skripsi]. Medan: Fakultas Kesehatan Masyarakat Universitas Sumatra Utara; 2005.

7. Amalia A, Lina N, Umi K, Ryan HP, Suandika M. Hubungan pelaksanaan oral hygiene dengan kejadian infeksi rongga mulut pada pasien cedera kepala dengan penurunan kesadaran di ruang 13 RSU Dr. Saiful Anwar Malang [homepage on the Internet]. 2010 [cited 2013 Aug 12]. Available from: http://madesehat.blogspot.com/2010/09 /oral-hygiene.html.

8. Vargas CM, Kramarow EK, Yellowitz JA. The Oral health of Older Americans [homepage on the Internet]. c2001. [updated 2001 Mar; cited 2013 Aug 10]. Available from: http://www.cdc. gov/nchs/data/ahcd/agingtrends/03oral. pdf.

9. Tjahja IN, Ghani L. Status kesehatan gigi dan mulut ditinjau dari faktor individu pengunjung puskesmas DKI Jakarta tahun 2007. Bul Penelit Kesehatan. 2010;38(2):52-66.

10. Herijulianti E, Indriani TS, Artini S. Pendidikan Kesehatan Gigi. Jakarta: Penerbit Buku Kedokteran EGC; 2001.

11. Efendi F, Makhfudli. Keperawatan Kesehatan Komunitas. Jakarta: Salemba Medika; 2009.

12. Natamiharja L, Dwi NS. Hubungan pendidikan, pengetahuan, dan perilaku ibu terhadap status karies gigi balitanya. Dentika Dental Journal. 2010;15(1):37-41.

13. Yulaikha E. Hubungan pengetahuan dan sikap lansia dengan praktek pencegahan cidera di Panti Werda Pucang Gading. Semarang [Skripsi]. Semarang: Fakultas Ilmu Keperawatan dan Kesehatan Universitas Muhammadiyah; 2006.

14. Cahyati WH. Beberapa faktor yang berhubungan dengan karies gigi pada lanjut usia (study kasus di Panti Werda Kota Semarang). Jurnal KEMAS. 2005;1(1):22-30.

15. Ratnasari NY. Pengaruh pendidikan kesehatan activities daily living (ADL) lansia terhadap pengetahuan dan sikap keluarga. Jurnal Keperawatan. 2010;1(1):9. 